Rev. Biol. Trop., 47(4): 939-948, 1999

www.ucr.ac.cr www.ots.ac.cr www.ots.duke.edu

\title{
Activity cycle of the pollen wasp, Trimeria howardi (Hymenoptera: Vespidae) in Southeastern Brasil
}

\author{
Maria Rita Mechi ${ }^{1}$
}

1 Departamento de Biologia, Faculdade de Filosofia Ciências e Letras de Ribeirão Preto, Universidade de São Paulo, 14040-901, Ribeirão Preto, SP, Brasil. Fax (016) 633 5015. E-mail: baiomv@usp.br

Received 16-XI-1998. Corrected 14-VI-1999. Accepted 16-VI-1999.

\begin{abstract}
Among the wasps, the Masarinae are a peculiar subfamily. It is the only group of wasps that provisions brood cells with pollen and nectar. The studied species Trimeria howardi Bertoni, 1911, was until recently abundant in Ribeirão Preto, São Paulo, southeastern Brazil. This paper deals with plant species visited by $T$. howardi, in relation to the species' annual cycle of activity, based on periods of nest foundation, flight activity, and development stages of immatures present in the cells. During the study period (five years) $T$. howardi visited four species of plants in two botanical families: Bidens pilosa L.(Asteraceae); Xanthium spinosum L. (Asteraceae); Stylosanthes guianensis (Aulb). Sw. (Leguminosae), and Zornia diphylla (L.) Pers. (Leguminosae). Based on the number of visited families, $T$. howardi can be considered a narrow polylectic species. In general, the species annual activity cycle consists of three phases: Active phase: January to July; Inactive phase: August - September; Active phase: October to December. The annual cycle is bivoltine or multivoltine and the diapause is facultative, because it occurs in a single generation during the year.
\end{abstract}

Key words: Hymenoptera, Vespidae, Trimeria howardi, phenology, annual cycle, Asteraceae, Leguminosae.

Divided into two tribes: Gayellini (two genera), and Masarini (11 genera), the subfamily Masarinae (sensu Carpenter 1993) is relatively small, with no more than 300 described species (Gess 1996).

While the tribe Gayellini is restricted to the Neotropical Region, the tribe Masarini is much more widespread, being represented in the Neartic, Neotropical, Palearctic, Afrotropical, and Australian Regions (Carpenter 1993, Gess 1996). The genus Trimeria belongs to the Masarini and its distribution is restricted to the Neotropical Region.

Masarinae, within the Vespoidea, are a peculiar subfamily, because they wasps feeds the immatures with pollen and nectar, as bees do; while the remaining wasps nourish their brood with animal protein. Besides, Masarinae wasps transport their provisions in the crop, a character of scarce occurence among bees. Indeed, only Colletidae bees (Hylaeinae and Euryglossinae) and Lestrimelitta (Apidae: Meliponinae) are exclusive crop pollen transporters (Michener 1974). Equally notable in the group are the morphological modifications associated with nectar collection: a prolonged and retractile proboscis (Carpenter 1997). The pollen wasps, like the long-tongued bees, therefore have the potential to obtain nectar from a wider range of flower 
forms than do short-tongued wasps and bees. However, the Masarinae are associated with a relatively small range of flower families visited by aculeata Hymenoptera (Gess 1996).

Pollen-wasps nest in cavities built in the soil, in pre-existing cavities, or build cell groups fastened to rocks or branches (Malyshev 1968, Gess 1996).

Trimeria howardi nests in the soil, in burrows dug by a female solitarily. The preferences are for areas where the vegetation is sparse, that is, quite sunny in well-drained soil (Mechi, in press).

This paper reports on plant species visited by $T$. howardi, and describes the species' annual life cycle, based on the periods of nest foundation, flight activity, and the developmental stages of the immatures found in the cells, throughout the year.

\section{MATERIALS AND METHODS}

The research was done for five years in the University of São Paulo Campus at Ribeirão Preto, São Paulo State, southeast Brazil $\left(21^{\circ} 11^{\prime} \mathrm{S} 47^{\circ} 48^{\prime} \mathrm{W}, 500\right.$ to $700 \mathrm{~m}$ alt. and $581.53 \mathrm{ha}$ ). The climate is savanna tropical dry winter (AW, according to Koeppen's classification), which is characterized by a very dry winter, and a hot and humid summer. The original vegetation was Cerrado (Brazilian savanna) and Semi-deciduous Mesophic Forest. Presently, the Campus area is covered by gardens, allied to reforestation with native plants, "capoeira" and discontinuous patches of very disturbed primitive semideciduous Mesophic Forest.

Plants visited by Trimeria howardi were censured by sweeping the plants with flowers according to Sakagami \& Matsumura (1967).

The flowering intensity was rated as: 1rare; 2 - some; 3 - quite, and 4- large number of plants with flowers.

The frequency of nests of $T$. howardi was estimated by a monthly census in five nesting sites. For this, quadrats were set as follows: analysis 40 quadrats of $1600 \mathrm{~m}^{2}$ (site A), 16 of
$400 \mathrm{~m}^{2}$ (site B), 66 of $400 \mathrm{~m}^{2}$ (site C), 25 of 25 $\mathrm{m}^{2}$ (site D) and 20 of $25 \mathrm{~m}^{2}$ (site E).

Each nest found was coded, mapped, enumerated with a plastic plate and afterwards fixed near the nest. In the initial phase of this investigation the old nests (commonly scars) were marked with a nail close to the nests to re-. cord probable reactivations.

All new nests recorded after each census were considered new foundations and "active nests" were those with adults (males or females). In this species, the adults lack diapause in all periods of the year.

The seasonal variations of the stages of development of the immature presents in the nests, as well as of the flight of the wasps were registered through daily observations and periodic excavations of the nests.

To verify if there were differences among the proportions of founded nests according to the rainfall (or temperature) and the year under consideration was calculated: $\mathrm{X}^{2}$, Pearson's contingency coefficient (C), and Goodman's test.

Months classification was based on monthly mean temperatures, and in the Index of effectiveness of the rainfall.

The monthly activity index was calculated by dividing daily flights frequency, to the frequency of monthly observations. Observations were organized fortnightly (during winter) and weekly (others seasons). Every daily observation period involved twelve hours (6:00 AM to 18:00 PM).

The area maps containning the nesting sites, and nests location can be seen in Mechi (1981), and Mechi (in press).

The specimens of the T. howardi was deposited by Soichi F. Sakagami at Hyogo University Agriculture Museum of Kobe University, Japan.

\section{RESULTS}

Visited plants: During the present study, Trimeria howardi visited four species of plants, of two botanical families: Bidens pilosa 
L. (Asteraceae); Xanthium spinosum L. (Asteraceae); Stylosanthes guianensis (Aulb.) Sw. (Leguminosae), and Zornia diphylla (L.) Pers. (Leguminosae). B. pilosa and S. guianensis were the species of plants more visited by $T$. howardi.

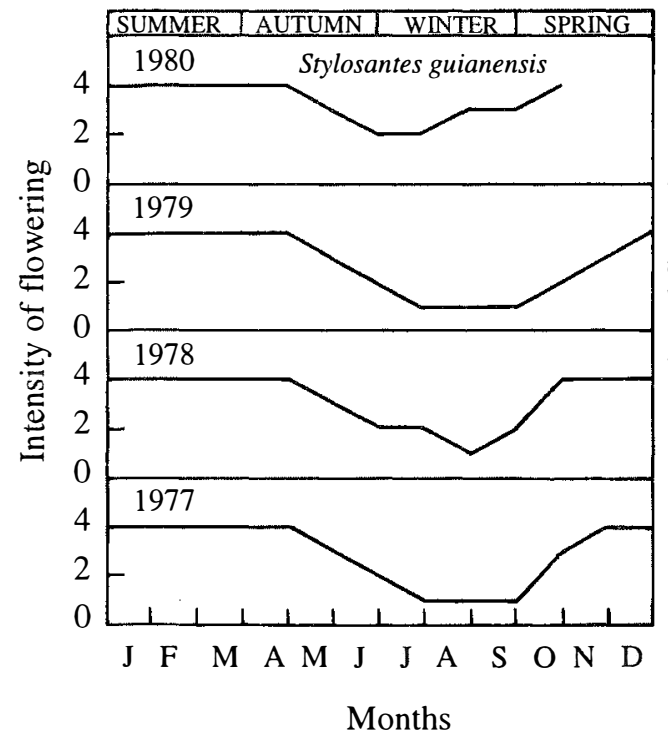

The largest flowering intensities of $S$. guianensis and of $B$. pilosa occurred in the spring and summer, periods peak activity of the species (Fig.1).

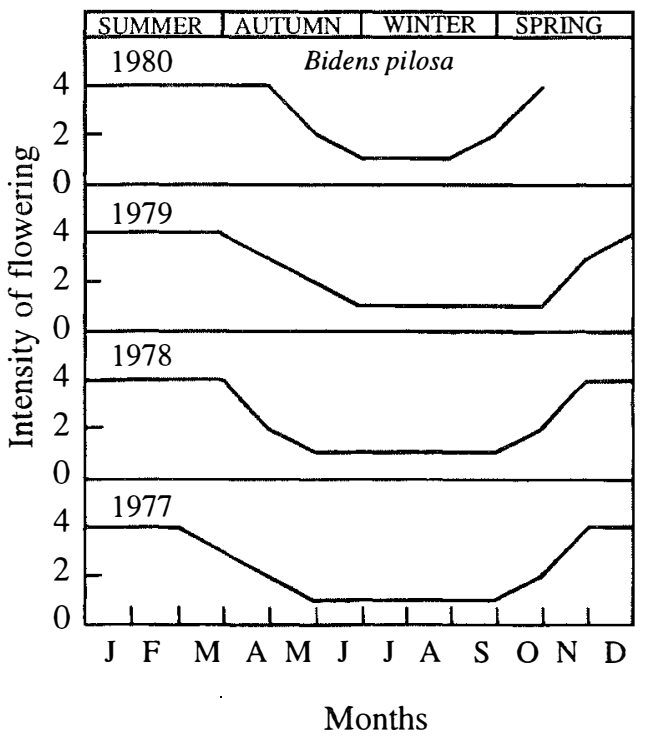

Fig. 1. Flowering phenology of Stylosanthes guianensis and of Bidens pilosa, in the Campus of Ribeirão Preto - USP.

Annual cycle of activity: Along the study 2739 nests were studied, in 5 nesting sites,with the following distribution: 2598 nests (Area A); 90(B); 11 (C); 26(D), and 14(E).

The monthly variations in the number of active nests and of foundations, related with the environmental factors ( rainfall, temperature and relative humidity), are shown in the Figs. 2 to 6. In addition, monthly indexes of flight activity, and monthly variations on immature development stages present in cells are shown in the Figs. 7 and 8, respectively.

In general, a relatively large number of active nests, foundations, immature in several developmental stages, and high flight activity were observed during the spring, summer and autumn. Conversely, low frequency or absence of foundations, and flight activity was verified in the winter (Figs. 2 to 8 ). At winter beginning, only immatures in the prepupa stage, were found in cell. At the end of this period, retaking on the development of the immature, starts. Effectively, immature in the pre-pupa stage, pupa and imago appear (Fig. 8).

Trying to verify relationships between period of abundance of foundations and environmental factors, statistical tests, were used. The analysis of the association test between year and rainfall in relation to founded nests, showed that association exists between year, rainfall and frequency of founded nests $\left(\mathrm{X}^{2}\right.$ calculated $=$ $385.72 \mathrm{X}^{2}$ critical $=15.51$ ), but the association degree was little pronounced $(C=0.36)$. 


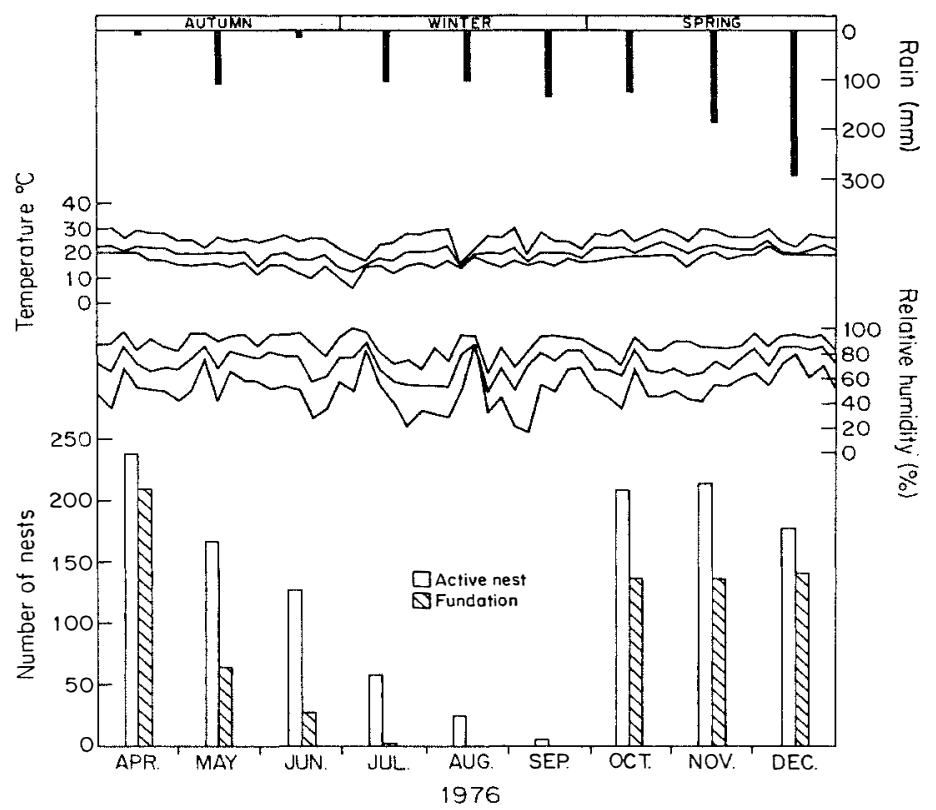

Fig. 2. Monthly variation in the number of active nests and of foundations, related to environmental factors (temperature, relative humidity and rainfall), in the period from april to december 1976.

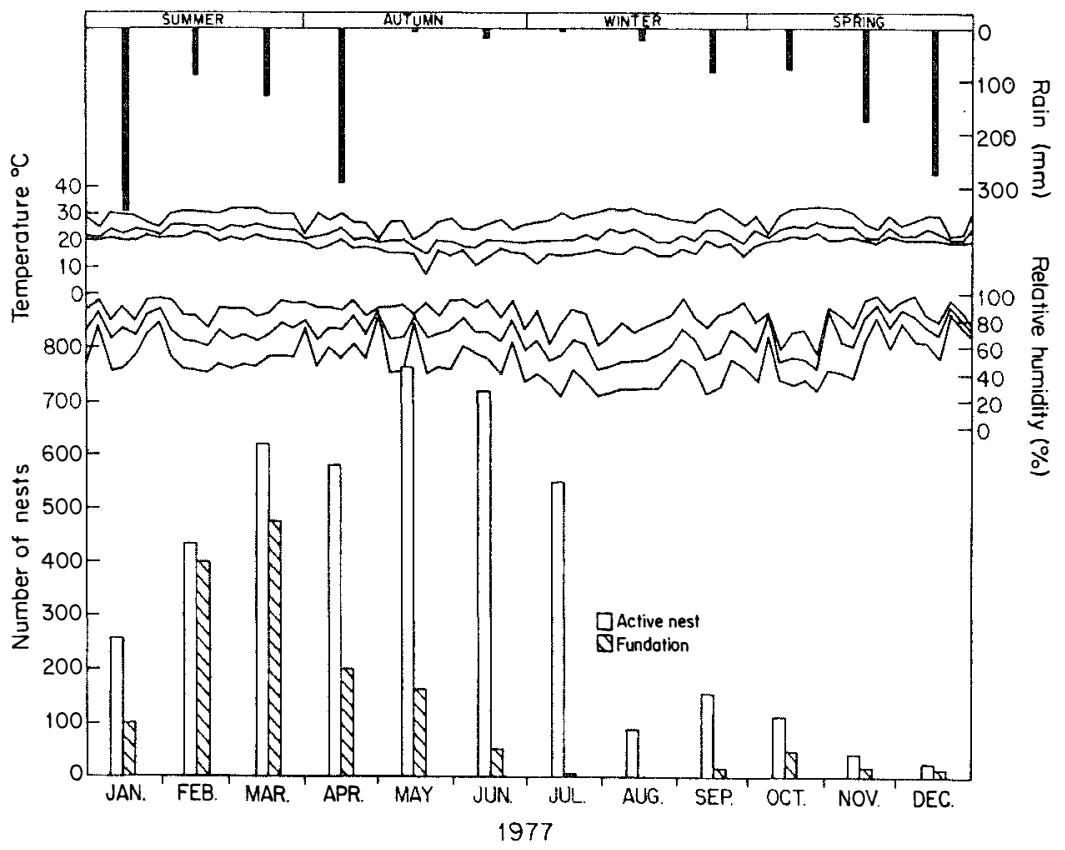

Fig. 3. Monthly variation in the number of active nests and of foundations related to environmental factors (temperature, relative humidity and rainfall), in 1977. 


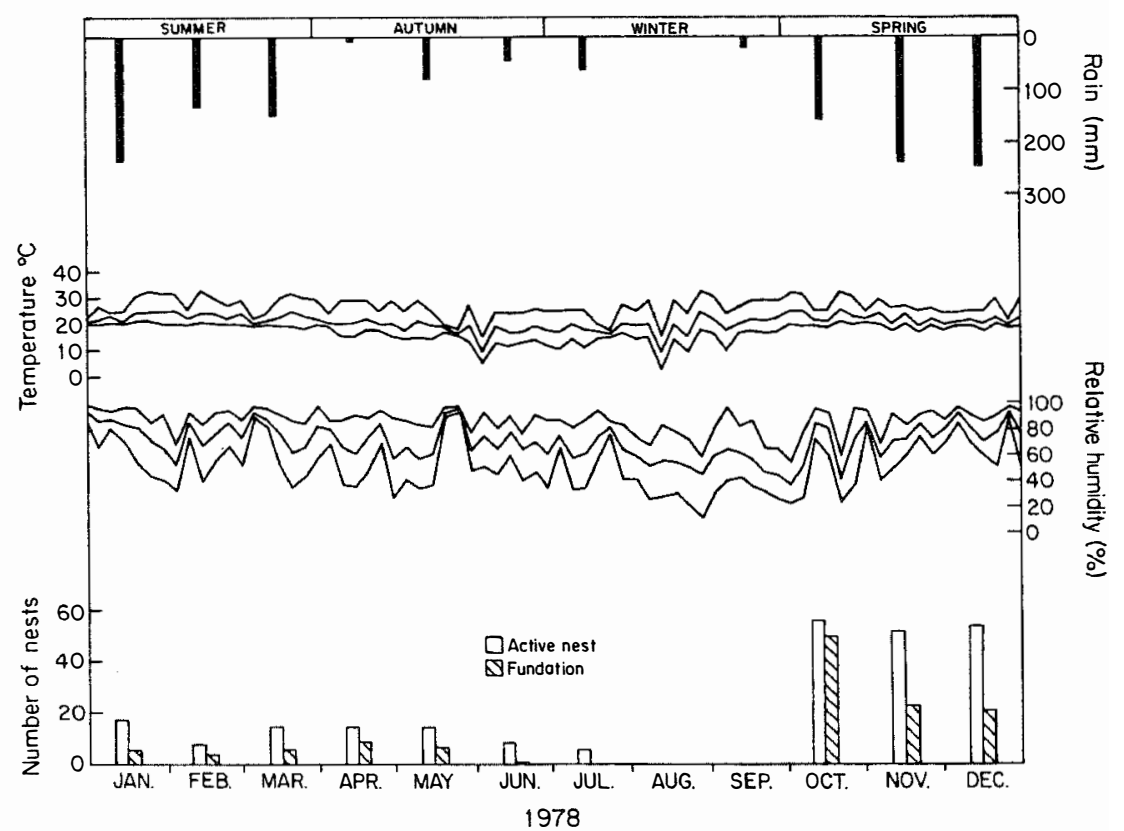

${ }^{7 i g . ~ 4 . ~ M o n t h l y ~ v a r i a t i o n ~ i n ~ t h e ~ n u m b e r ~ o f ~ a c t i v e ~ n e s t s ~ a n d ~ o f ~ f o u n d a t i o n s ~ r e l a t e d ~ t o ~ e n v i r o n m e n t a l ~ f a c t o r s ~(t e m p e r a t u r e, ~ r e-~}$ lative humidity and rainfall), in 1978.

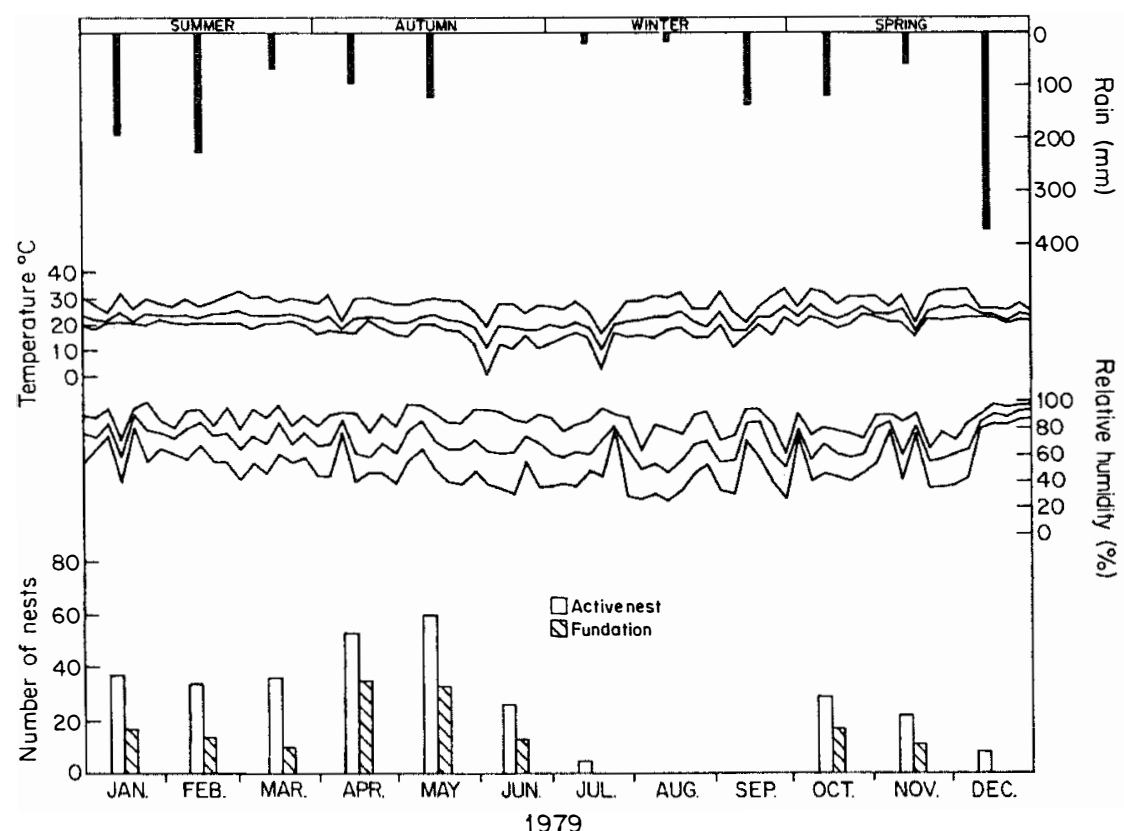

Fig. 5. Monthly variation in the number of active nests and of foundations related to environmental factors (temperature, relative humidity and rainfall), in 1979. 


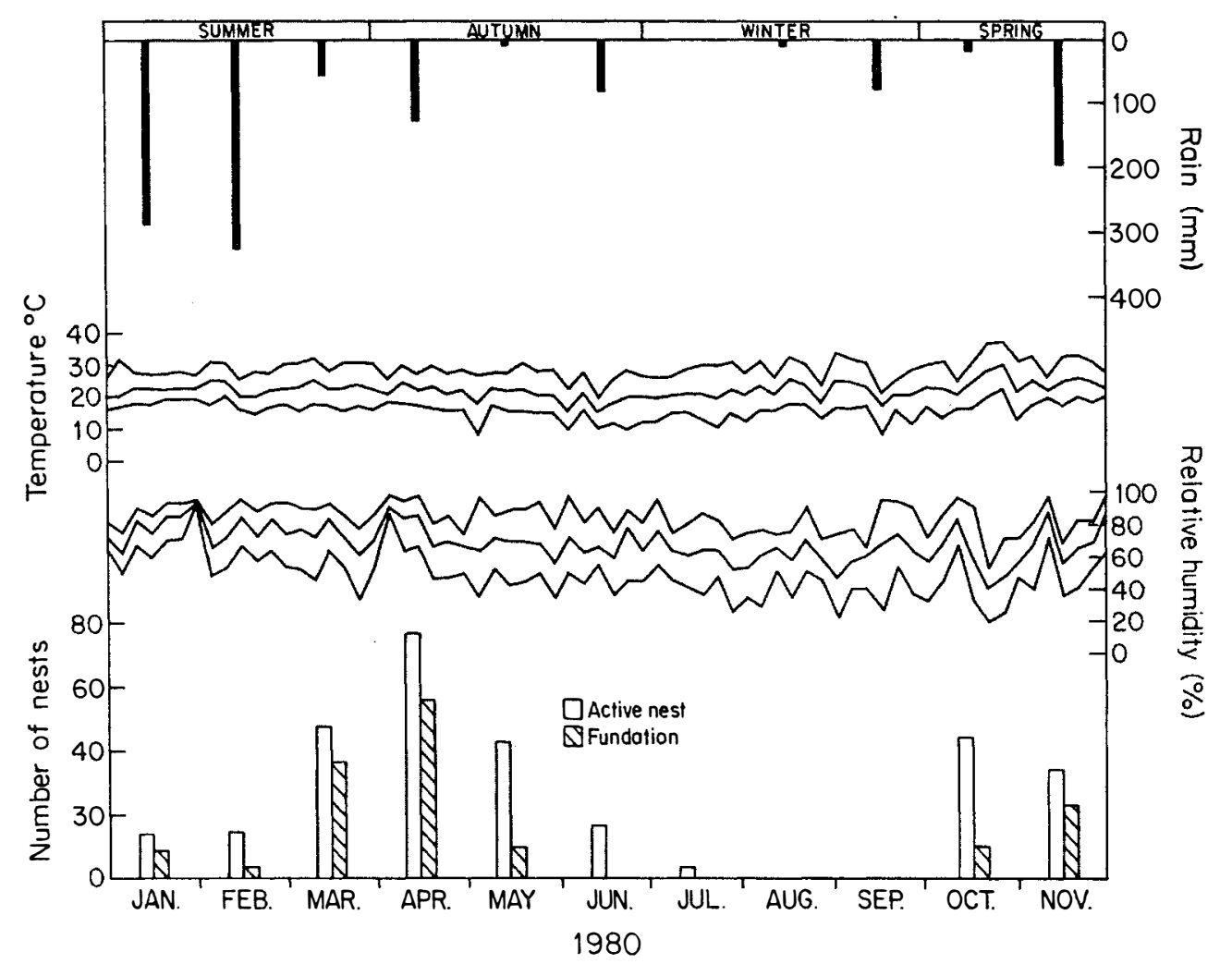

Fig. 6. Monthly variation in the number of active nests and of foundations related to environmental factors (temperature, relative humidity and rainfall), in 1980 .

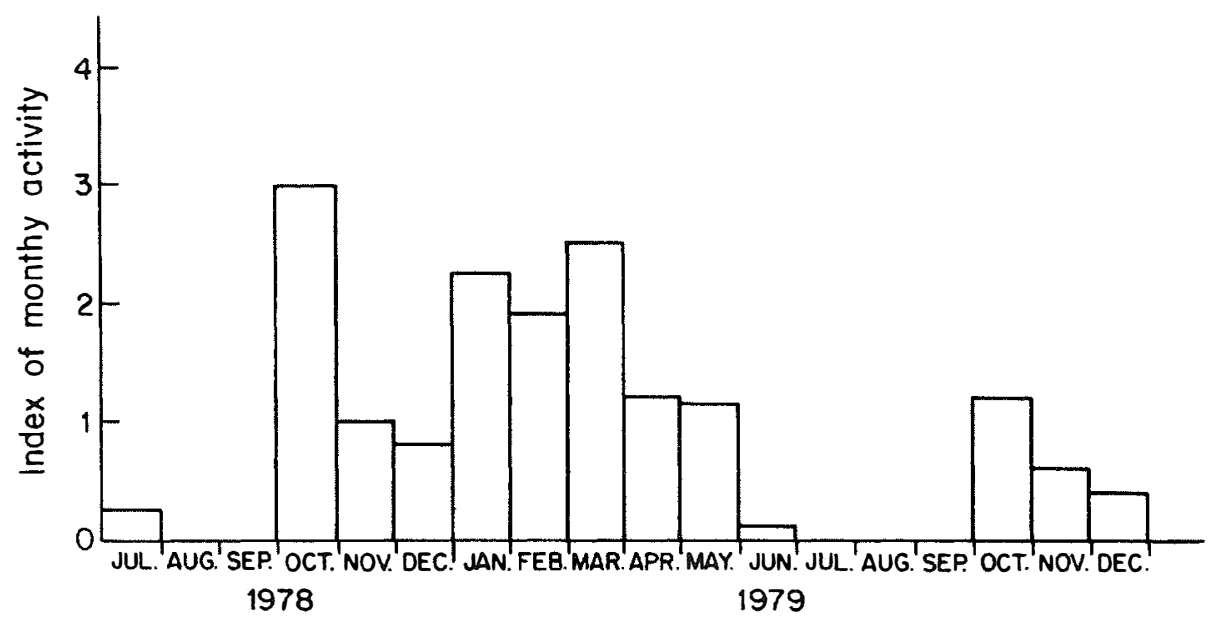

Fig. 7. Monthly index of the flight ativity of Trimeria howardi, in the period ranging from July to December of 1978, and January to december of 1979. $\mathrm{N}=108$ days and 1296 hours. 


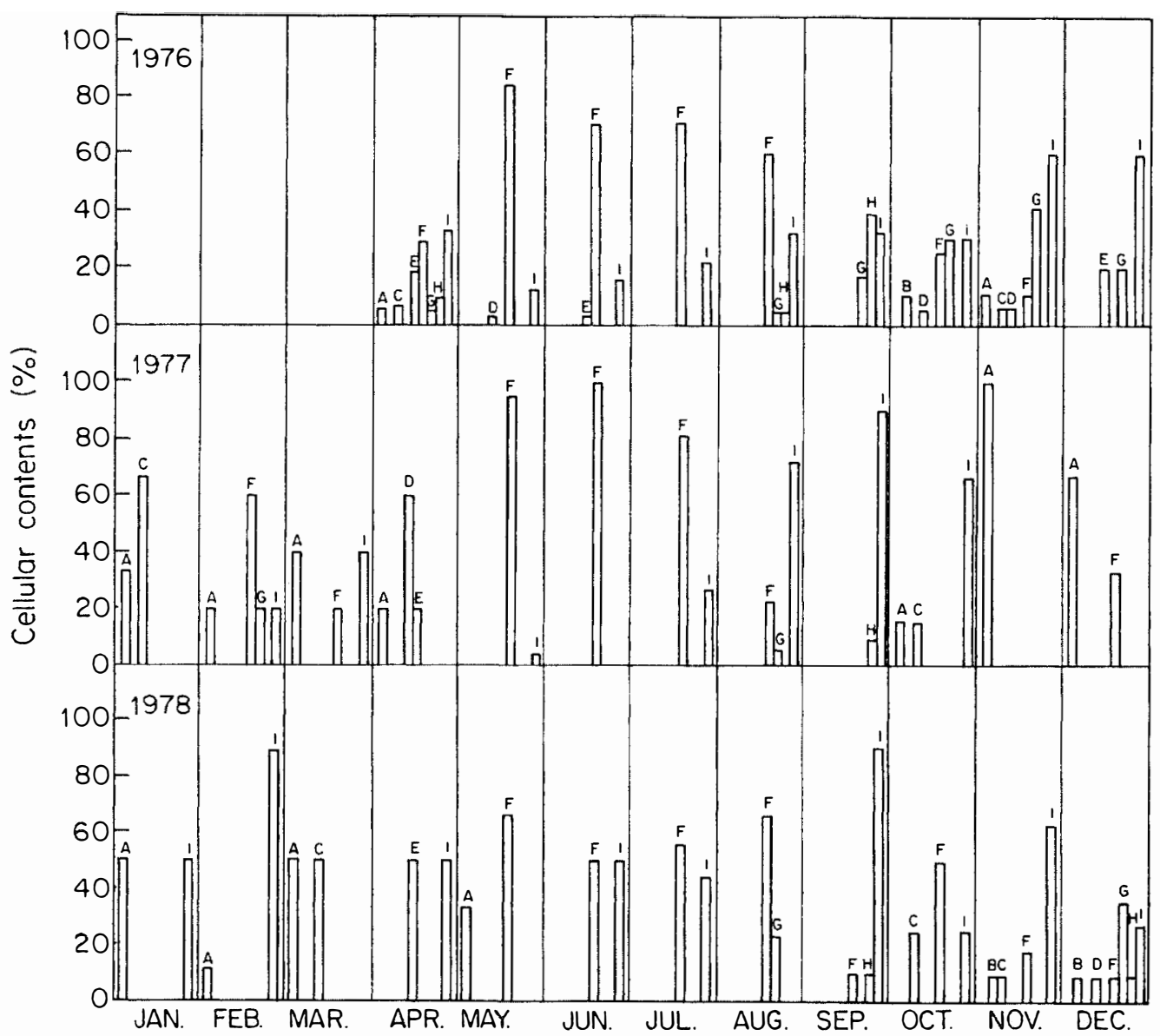

Fig. 8. Annual variation of brood cell content in the nests of Trimeria howardi, opened for study in 1976 to 1978 . A $=$ New cell $; \mathrm{B}=$ Provision C = Provision and egg; $\mathrm{D}=$ Provision and larva $\mathrm{E}=$ Larva mature; $\mathrm{F}=$ Pre-pupa; $\mathrm{G}=\mathrm{Pupa} ; \mathrm{H}=\mathrm{Ima}-$ go; $\mathrm{I}=$ Old cell; $\mathrm{n}=126$ nests and 332 cells.

On the other hand, analysis of the association between year and classified temperature, in relation to founded nests, it showed that association exists between year, temperature, and founded nests $\left(\mathrm{X}^{2}\right.$ calculated $=178.0852 \mathrm{X}^{2}$ critical $=9.49$ ), but the association degree was little pronounced $(\mathrm{C}=0.2209)$.

The results of the contrast among proportions of founded nests, in relationship to rainfall, inside each of the multinomials (year), were as proceed: For 1976, the proportion of founded nests follows the following order: Very humid>arid>humid. In 1977, humid>very humid> arid. For the very humid 1978 year, $>$ (humid $=$ arid). In relation to 1979 , arid $<$ (very humid=humid). For 1980, very humid $>$ humid arid.

The test of the contrast among proportions of foundations in relation to classified temperature, inside each multinomials (year) presented the following results: For 1976, the proportion of founded nests was higher in the periods classified as tropical. In 1977, the proportions did not differ from tropical to sub-tropical. In the tropical year of 1978, > sub-tropical. Whereas, in 1978, sub-tropical>tropical. Finally, in 1989, tropical >sub-tropical. 


\section{DISCUSSION}

Female pollen wasps, like all non-parasitic bees, visit flower to collect pollen and nectar to provision their nests similarly to most nonmasarinae aculeate wasps and bees, both male and female masarine collect nectar for their own nourishment (Gess 1996).

Trimeria howardi, in the Masarinae subfamily, is a species with narrow polylecty, because it collected pollen in only two families of plants and four species.

In other members of this subfamily there are evidence of oligolecty (Cooper 1952, Houston 1984, 1986, Gess 1992, 1996, Gess \& Gess 1989). Brood polylecty, in this group, seems to be an exception (Gess 1996).

T. howardi have a prolonged tongue ( $\mathrm{X}=$ $3,74 \mathrm{~mm}, \mathrm{SD}=0,25 \mathrm{~mm}$; Maximum $=4,37 \mathrm{~mm}$, Minimum $=3,29 \mathrm{~mm}, \mathrm{n}=82$ ), retractile proboscis, and reduced paraglossa. In another Masarinae, the length of the tongue varied from $1.48 \mathrm{~mm}$ in Paragia odyneuroides to $6.23 \mathrm{~mm}$ in Ceramius metanotalis (Gess 1996).

Analysing seasonal variations in the abundance of foundations, in flight activity and in immatures stages in nests (Figs. 2 to 8), it is sugested that the annual cycle of activity of $T$. howardi consists of two active phases, separated by an inactive phase. The active phase occurs from January to June-July, and from October to December, as well; while the inactive phase appears in August-September.

In the active phases, nest foundations occur allied to flight activity and immatures' presence according to various developmented stages. Conversely, in the inactive phase were noticed absence of foundations and of flight activity (Figs. 2 to 8 ) were the rule. In general, active nests collected in the winter contained senile females or males, and the new nests contained only a shaft (Mechi, 1981).

The results of the tests among the proportions of founded nests, in relation to rainfall and temperature, inside each year (multinomials), showed that larger proportions of founded nests happened in the periods classified as very humid, humid and tropical.
In the periods with absence of nests, the humidity of the soil (from surface $20 \mathrm{~cm}$ deep) varied from $13.7 \%$ to $17.10 \%$. In the other periods, the humidity in the same soil layer, oscillated from $12.59 \%$ to $51.09 \%$.

After Figs. 2 to 7, it can be stated that cycle of activity of $T$. howardi is synchronous. Studies carried out in the Ribeirão Preto region, in the same period, involving Polybia paulista Ihering (Simões \& Mechi 1983), Polistes versicolor versicolor (Olivier) (Gobbi \& Zucchi 1980) and Spilomena sp. (Carvalho \& Zucchi 1989) showed asynchronous nest's foundation, that is, foundations occur all year round independently of environmental conditions. Decreased foundations abundance in driest periods, were observed in those groups.

The presence of only pre-pupa immatures in the period of June- July in T. howardi, suggests interruption in the development (diapause). Similar fact occurs in the other Masarinae. In the group, the overwintering stage is the last-instar larva, which after it has finished feeding spin a cocoon and then enters a resting prepupal phase (Gess 1996).

Mechi (1981) evidences diapause occurrence, in the study of nests' cicle in T. howardi. Nests founded in the period ranging from october to may presented shorter ontogenetical period, as immatures' emergence accurred after 4-16 days when the founder female had left the nest.Moreover, nests founded at the end of that period presented an enlarged ontogenesis. Indeed, in some nests emergence of the immature occurred from 87-132 days after the founder had left the nest. So, in this species, the life cycle is bivoltine (Zucchi et al 1976) or multivoltine. Diapause, however is facultative, because it happens in only a generation during the year.

The life cycle pollen wasps in general, appears to be univoltine. The fligth period in winter-rainfall areas -was spring to early summer, and in areas receiving spring and autumn or summer rainfall it is early summer to late summer (Gess 1996).

Several factors have been suggested as responsible for the diapause: Temperature, humidity, photoperiod, quality and quantity of 
food, physiology of the female, competition for food, etc.

In temperate regions diapause is generally concerned with survival during cold winters when normal growth is not possible. In the tropics it may facilitates survival during the dry season, which is characterised by a lack of moisture and food (Chapman 1988).

It is important to point out, that during the period when diapause happened, the values of the relative humidity and of the temperature were lower (even so, inside of the limits of the development of insects), the rain-fall was lowers (Figs. 2 to 6), food was scarce (Fig. 1), and soil dry (13.77\% to $17.10 \%)$.

Besides, flutuation in the abundance of active nests and of foundations, along the year, these factors also varied from one year to another.

Several factors can be pointed as responsible for these variations: Abundance of nests in the precedent period, populational density of each nest and its composition, predators and parasites attacks, anthropic action, dispersion rates, environmental factors, etc.

In relation to the climatic factors, association tests among year, temperature, and rainfall in relation to foundations, by means of Pearson $\not$ s Contingency Coefficient showed that an association exists among these variables, but association degree among them is not very stronger. The fall in the number of foundations per year, results from interactions between biotic and abiotic factors.

Ecologically it is difficult to differentiate effect-cause, and many causes that seemingly are natural consequences of the population cycles, can be just collateral effects of the cyclic changes of the population (Pianka 1974).

High frequency of nests that are abandoned without leaving descendants (107 foundations in a sample of 116), a number relatively big of nests ( 26 nests and 50 cells in a sample of 119) with cell wholesales for parasites and predators, and great number of nests with offspring that were only constituted for males, can be some indicators of the variations. In this species, every females is a potential founder.
Absence of $T$. howardi in this campus, where was abundant before, is important. Although causes of such drastic changes are unknown, removal of host plants (to plant other garden species) and excessive grass trimming in the main nesting spots may have played a role.

\section{ACKNOWLEDGEMENTS}

This research is a part of a project financied by Fundação de Amparo à Pesquisa do Estado de São Paulo (FAPESP), and Conselho Nacional de Desenvolvimento Científico e Tecnológico (CNPq). Special thanks are given to Ronaldo Zucchi for his corrections on the typescript, Paulo Roberto Curi for statistical analysis, Soichi F. Sakagami (in memoriam) and Abrahan Willink (in memoriam) for identification of the species. We are also grateful to José Carlos Serrano for field aid and Mário Valentim Baio typing of the paper.

\section{REFERENCES}

Carpenter, J.M. 1993. Biogeographic pattem in the Vespidae: Two views of Africa and South America 139-155. In P. Goldblatt (ed). Biological relationships between Africa and South America. Yale, New Haven, Connetticutt.

Carpenter, J.M. 1997. Generic classification of the Australian pollen wasps (Hymenoptera: Vespidae; Masarinae). J. Ent. Soc. 69: 384-400.

Carvalho, L.M. \& R. Zucchi. 1989. Aspectos fenológicos de Spilomena sp (Hymenoptera, Sphecidae, Pemphredoninae). Rev. Brasil. Biol. 49: 799-807.

Chapman, R.F. 1988. Structure and Function. Elsevier, New York. 819 p.

Cooper, K.W. 1952. Records and flower preferences of Masaridae wasps. II. Polytropy or oligotropy in Pseudomasaris (Hymenoptera, Vespidae). Amer. Midland Nat. 48:103-110.

Gess, S.K. 1992. Biogeography of the masarine wasps (Hymenoptera: Vespidae: Masaridae), With particular emphasis on the southern African taxa and on correlations between masarine and forage plant distributions. J. Biogeogr. 19: 491-503. 
Gess, S.K. 1996. The pollen wasps. Ecology and Natural History of the Masarinae. Harvard University, Cambridge. $340 \mathrm{p}$.

Gess, S.K. \& F.W. Gess, 1989. Flower visiting by masarid wasps in Southern Africa (Hymenoptera: Vespidae: Masarinae). Ann. Cape Prov. Mus. (Nat. Hist.) 18: 95-134.

Gobbi, N.\& R. Zucchi. 1980. On the ecology of Polistes versicolor versicolor (Oliver) in southern Brasil. I Phenological account. Naturalia 5: 97-104.

Houston, T.F. 1984. Bionomic of a pollen-collecting wasp, Paragia tricolor wasps (Hymenoptera: Vespidae; Masarinae) in Western Australia. Rec. West. Aust. Mus. 11: 141-151.

Houston, T.F. 1986. Biological notes on the pollen wasp, Paragia (Cygnaea) vespiforms (Hymenoptera: Vespidae: Masarinae) with description of a nest. Aust. Ent. Mag. 12: 115-119.

Malyshev, S.I. 1968. Genesis of the Hymenoptera and phase of their evolution. Methuen, London. 319p.

Mechi, M.R. 1981. Estudo da ecologia de Trimeria howardi (Masaridae, Vespoidea). Tese de Mestrado em Ecologia e Recursos Naturais, Universidade Ferderal de São Carlos, São Carlos, São Paulo, Brasil
Mechi, M.R. 1983. Nesting behavior and ditribution of nests in the pollen wasp Trimeria howardi (Masarinae - Vespoidea). Naturalia, in press.

Michener, C.D. 1974. The social behavior or the bees. A comparative study. Belcknap, Cambridge. 404p.

Pianka, R.E. 1974. Evolutionary ecology. Harper, New York. $356 \mathrm{p}$.

Sakagami, S. \& T. Matsumura. 1967. Relative abundance, Phenology and preference of andrenid bees in Sapporo, north Japan (Hymenoptera, Apoidea). Jap. J. Ecol. 17: 237-251.

Simões, D. \& M.R. Mechi. 1983. Estudo sobre a fenologia de Polybia (Myapetra) paulista Ihering, 1896 (Hymenoptera, Vespidae). Naturalia 8: 185-191.

Zucchi, R., S. Yamane \& S. Sakagami. 1976. Preliminary notes on the habits of Trimeria howardi a neotropical communal masarid wasp, with description of the mature larva (Hymenoptera: Vespoidea). Ins. Matsum. 8: 47-57. 